\title{
Radiotherapy for tumors of the stomach and gastroesophageal junction - a review of its role in multimodal therapy
}

Daniel Buergy ${ }^{1 *}$, Frank Lohr ${ }^{1}$, Tobias Baack ${ }^{1}$, Kerstin Siebenlist ${ }^{1}$, Stefan Haneder ${ }^{2}$, Henrik Michaely ${ }^{2}$, Frederik Wenz ${ }^{1}$ and Judit Boda-Heggemann ${ }^{1}$

\begin{abstract}
There is broad consensus on surgical resection being the backbone of curative therapy of gastric- and gastroesophageal junction carcinoma. Nevertheless, details on therapeutic approaches in addition to surgery, such as chemotherapy, radiotherapy or radiochemotherapy are discussed controversially; especially whether external beam radiotherapy should be applied in addition to chemotherapy and surgery is debated in both entities and differs widely between regions and centers. Early landmark trials such as the Intergroup-0116 and the MAGIC trial must be interpreted in the context of potentially insufficient lymph node resection. Despite shortcomings of both trials, benefits on overall survival by radiochemotherapy and adjuvant chemotherapy were confirmed in populations of D2-resected gastric cancer patients by Asian trials.

Recent results on junctional carcinoma patients strongly suggest a survival benefit of neoadjuvant radiochemotherapy in curatively resectable patients. An effect of chemotherapy in the perioperative setting as given in the MAGIC study has been confirmed by the ACCORD07 trial for junctional carcinomas; however both the studies by Stahl et al. and the excellent outcome in the CROSS trial as compared to all other therapeutic approaches indicate a superiority of neoadjuvant radiochemotherapy as compared to perioperative chemotherapy in junctional carcinoma patients. Surgery alone without neoadjuvant or perioperative therapy is considered suboptimal in patients with locally advanced disease.

In gastric carcinoma patients, perioperative chemotherapy has not been compared to adjuvant radiochemotherapy in a randomized setting. Nevertheless, the results of the recently published ARTIST trial and the Chinese data by Zhu and coworkers, indicate a superiority of adjuvant radiochemotherapy as compared to adjuvant chemotherapy in terms of disease free survival in Asian patients with advanced gastric carcinoma. The ongoing CRITICS trial is supposed to provide reliable conclusions about which therapy should be preferred in Western patients with gastric carcinoma. If radiotherapy is performed, modern approaches such as intensity-modulated radiotherapy and image guidance should be applied, as these methods reduce dose to organs at risk and provide a more homogenous coverage of planning target volumes.
\end{abstract}

Keywords: Stomach, Gastric cancer, Gastroesophageal junction, Radiotherapy, Adjuvant therapy, Neoadjuvant, Radiochemotherapy

\footnotetext{
* Correspondence: daniel.buergy@umm.de

${ }^{1}$ Department of Radiation Oncology, Universitätsmedizin Mannheim, Medical

Faculty Mannheim, Heidelberg University, Mannheim, Germany

Full list of author information is available at the end of the article
} 


\section{Introduction}

Although mortality in gastric cancer has declined rapidly during the last century and continues to decrease [1], it still accounts for 10,340 deaths [2] per year in the US and $8.1 \%$ of all cancer deaths in Europe [3]. Worldwide, gastric cancer is the fourth and fifth most common cancer in males and females [4]. While overall gastric cancer incidence is decreasing, the incidence of adenocarcinoma of the gastric cardia and of the lower esophagus is increasing in most developed Western populations [5-7]. In Eastern populations, where gastric carcinoma in general is more common, adenocarcinomas of the gastroesophageal junction (GEJ) are still rare [8,9]. It is unclear, if this is caused by an absence of Western risk factors, such as obesity [10], smoking, and drinking habits [11] in Eastern patients. Epidemiologic studies in Japan even suggested that the mentioned (Western) risk factors are not related to the occurrence of GEJ carcinoma in Asian patients [8]. The shift of gastric cancer location towards cardia and GEJ, as well as the histological trend from squamous cell carcinoma (SCC) to adenocarcinoma in Western populations creates currently changes in the basis for therapeutic recommendations.

This review summarizes most recent data of Eastern and Western trials on gastric and junctional cancer treatment in addition to surgery. We provide in detail a comparison of the newer results with early landmark trials and discuss technical approaches when radiotherapy is performed in addition to chemotherapy (CT) and surgery.

\section{Classification of GEJ carcinoma - gastric, esophageal, or as an own entity}

Whether GEJ adenocarcinomas should be classified as gastric or esophageal carcinomas or as an own entity is an issue that has been discussed for years [12-14]. The classification proposed by Siewert et al. [13] distinguished three types of GEJ carcinoma, Type I being considered as adenocarcinoma of the distal esophagus, infiltrating the GEJ from above, Type II being the true carcinoma of the cardia arising immediately at the GEJ, and Type III, the subcardial gastric carcinoma that infiltrates the GEJ from below. Although this classification was based purely on anatomical/topographic parameters, it was accepted by most surgeons $[15,16]$. In the $7^{\text {th }}$ American Joint Committee on Cancer (AJCC) staging manual $[17,18]$ GEJ cancer is now classified as esophageal cancer even within the first $5 \mathrm{~cm}$ of the stomach if it invades the junction, meaning that in addition to Siewert I, the former Siewert II and even Siewert III lesions are now both classified as esophageal carcinoma [17]. This new classification which is currently not accepted by all authors [16] makes an appropriate interpretation of results from therapeutic trials difficult, as
GEJ carcinomas that were formerly classified as gastric carcinoma are now staged as esophageal carcinoma.

Taken together, there is an ongoing discussion about classification of GEJ carcinomas as gastric or esophageal cancer. They were included in clinical trials on both cancers. Therefore detailed knowledge of the respective population in each trial is necessary when results of esophageal or gastric cancer trials are applied to GEJ adenocarcinoma patients.

\section{The dispute on lymph node dissection}

With regard to the high incidence of gastric and the increasing incidence of GEJ carcinoma, it comes as a surprise that therapeutic approaches differ widely in terms of surgical approach especially concerning extended vs. limited lymph node dissection [19-22], and (neo-) adjuvant therapy. Basically, according to the classification by the Japanese Gastric Cancer Association (JGCA), most perigastric lymph nodes are defined as group 1, whereas the distant perigastric nodes, the nodes along the common hepatic artery, splenic artery, celiac axis and proper hepatic artery are defined as group 2 [23]. In the discussion about lymph node resection, most surgeons of the Western world favored a limited en bloc resection of group 1 nodes with the stomach (D1) because of increased perioperative mortality associated with the additional resection of group 2 nodes (D2) [19,21].

In contrast to the trials in the West, in Eastern trials, extended resection (D2) approaches for gastric carcinoma were applied with good results since the 1960s [23]. Current data from Western populations are indicating an emerging consensus that D2 resection with sparing of pancreas and spleen (also called D1+) is not associated with increased perioperative mortality [20,22]. Although a recent update of the Dutch D1D2 trial [20] indicated a significantly decreased gastric cancer-related death rate in the $\mathrm{D} 2$ group as compared to D1, it remains to be proven whether D2/D1+ vs. D1 resection in Western populations significantly increases overall survival (OS) [24].

When it comes to lymphadenectomy in esophageal carcinomas of the lower third and in GEJ adenocarcinomas, two-field lymphadenectomy with dissection of lymph nodes in the lower half of the chest and in the upper abdominal compartment has been widely accepted as a compromise between the benefits of extended surgery and postoperative morbidity [25].

In gastric- and GEJ carcinoma, therefore, the best surgical approach is still discussed, especially regarding the extension of lymph node dissection. Although surgical techniques have been improved greatly during the last years, there is still a high rate of failure in local control [26] as well as a high rate of distant metastases, stressing the importance of systemic and local therapeutic approaches in addition to surgery. 
Table 1 Patient characteristics, side effects and survival in different gastric cancer trials

\begin{tabular}{|c|c|c|c|c|c|c|}
\hline Clinical Trial & INT-0116 & MAGIC & ACTS-GC & CLASSIC & ARTIST & Zhu 2012 \\
\hline Number of patients & 556 & 503 & 1059 & 1035 & 458 & 380 \\
\hline Tumor location & Stomach: $80 \%$ GEJ: $20 \%$ & $\begin{array}{l}\text { Stomach: } 74 \% ; \\
\text { esophagus: } 14.5 \% ; \\
\text { GEJ: } 11.5 \%\end{array}$ & $100 \%$ stomach & $\begin{array}{l}\text { 97.7\% stomach; } \\
2.3 \% \text { GEJ }\end{array}$ & $100 \%$ stomach & $\begin{array}{l}\text { 80.5\% stomach; } \\
19.5 \% \text { GEJ }\end{array}$ \\
\hline Treatment in CT/CRT arm & $\begin{array}{l}\text { Resection (D2: 10\%), } \\
\text { adjuvant FU/FA with } \\
\text { 45/1.8Gy* }\end{array}$ & $\begin{array}{l}\text { Perioperative } 6 \text { cycles } \\
\text { of FU/epirubicin/cisplatin; } \\
\text { D2 resection in } 42.5 \%{ }^{+}\end{array}$ & $\begin{array}{l}\text { D2 (94.7\%) or } \\
\text { D3 (5.3\%) surgery; } \\
\text { adjuvant S-1 }\end{array}$ & $\begin{array}{l}\text { D2 surgery; } \\
\text { Adjuvant } \\
\text { capecitabine } \\
\text { and oxaliplatin }\end{array}$ & $\begin{array}{l}\text { D2 resection, } \\
\text { adjuvant } X P \text {, } \\
45 / 1.8 \mathrm{G} / \text { capecitabine; } \\
2 \text { cycles } X P^{\S}\end{array}$ & $\begin{array}{l}\text { D2 resection; } \\
1 \text { cycle adjuvant } \\
\text { FU/FA; 45/1.8Gy } \\
\text { IMRT/FU/FA; } \\
\text { followed by } 2 \\
\text { cycles FU/FA }\end{array}$ \\
\hline Treatment in control arm $^{\neq}$ & $\begin{array}{l}\text { Resection alone } \\
(\mathrm{D} 2: 10 \%)^{*}\end{array}$ & $\begin{array}{l}\text { D2 resection in } \\
40.4 \% \text { of } \text { cases }^{\dagger}\end{array}$ & $\begin{array}{l}\text { D2 (93.8\%) or } \\
\text { D3 (6\%) resection } \\
\text { (D1 in } 0.2 \%)\end{array}$ & D2 surgery & $\begin{array}{l}\text { D2 surgery; } \\
\text { adjuvant XP }\end{array}$ & $\begin{array}{l}\text { D2 resection; } \\
\text { adjuvant FU/FA } \\
\text { only }\end{array}$ \\
\hline $\begin{array}{l}\text { AJCC/UICC stage (or TNM) } \\
\text { in CT/CRT arm }\end{array}$ & $\begin{array}{l}\text { T1-2: 31\%; T3-4: 69\%; } \\
\text { N0: } 16 \% ; \mathrm{N}+: 84 \%{ }^{\neq \neq}\end{array}$ & $\begin{array}{l}\text { T1-2: 51.7\%; T3-4: } \\
\text { 48.3\%; N0: 31.1\%; } \\
\text { N+: 68.9\% } \neq \neq\end{array}$ & $\begin{array}{l}\text { II: 44.6\%; IIIA: 38.2\%; } \\
\text { IIIB: } 17.0 \% ; \text { IV: } 0.2 \%\end{array}$ & $\begin{array}{l}\text { IB: <1\%; II: 49\%; } \\
\text { IIIA: 37\%; } \\
\text { IIIB: 14\%; IV: } 0 \%\end{array}$ & $\begin{array}{l}\text { IB: 21.3\%; II: 36.5\%; } \\
\text { IIIA: 23\%; IIIB: } 7.8 \% \\
\text { IV: } 11.3 \%\end{array}$ & $\begin{array}{l}\text { IB: 10.8\%; II: 19.4\%; } \\
\text { III: 55.4\%; IV: 14.5\% }\end{array}$ \\
\hline $\begin{array}{l}\text { AJCC/UICC stage (or TNM) } \\
\text { in control }{ }^{\ddagger} \text { arm }\end{array}$ & $\begin{array}{l}\text { T1-2: 31\%; T3-4: 68\%; } \\
\text { NO: 14\%; N+: 85\%" }\end{array}$ & $\begin{array}{l}\text { T1-2: } 36.8 \% ; \\
\text { T3-4: } 63.2 \% ; \\
\text { N0: } 26.9 \% ; \\
\text { N+: } 73.1 \%\end{array}$ & $\begin{array}{l}\text { II: 44.9\%; IIIA: 39.1\%; } \\
\text { IIIB: 16.0\%; IV: 0\% }\end{array}$ & $\begin{array}{l}\text { I: } 0 \% ; \text { II: 51\%; } \\
\text { IIIA 36\%; IIIB 13\%; } \\
\text { IV: <1\% }\end{array}$ & $\begin{array}{l}\text { IB: } 21.9 \% ; \text { II: } 37.7 \% ; \\
\text { IIIA: } 21.1 \% ; \text { IIIB: } 7.5 \% ; \\
\text { IV: } 11.8 \%\end{array}$ & $\begin{array}{l}\text { IB: 9.1\%; II: 18.2\%; } \\
\text { III: 58.2\%; IV: } 14.5 \%\end{array}$ \\
\hline OS in CT/CRT arm ${ }^{\#}$ & $\begin{array}{l}\text { 3-yr: 50\% ( } p=0.005) \\
\text { 5-yr: 42\% }\end{array}$ & $\begin{array}{l}\text { 3-yr: } 42 \% \\
\text { 5-yr: 36.3\% ( } p=0.008)\end{array}$ & $\begin{array}{l}3 \text {-yr: } 80.1 \%(p=0.003) \\
5 \text {-yr: } 71.7 \%\end{array}$ & 3-yr: 83\% ( $p=0.0493)$ & Unspecified & $\begin{array}{l}5-y r: 48.4 \% \\
(p=0.122) \\
3-y r: \sim 62 \%\end{array}$ \\
\hline OS in control arm $^{\#}$ & 3-yr: $41 \%(p=0.005)$ & $\begin{array}{l}3 \text {-yr: } 31 \% \\
\text { 5-yr: } 23.0 \%(p=0.008)\end{array}$ & $\begin{array}{l}\text { 3-year: } 70.1 \% \\
\text { ( } p=0.003) \\
\text { 5-yr: } 61.1 \%\end{array}$ & $\begin{array}{l}3 \text {-yr: } 78 \% \\
(p=0.0493)\end{array}$ & Unspecified & $\begin{array}{l}5 \text {-yr: } 41.8 \% \\
\text { (p=0.122) } \\
\text { 3-yr: } 53 \%\end{array}$ \\
\hline DFS in CT/CRT arm ${ }^{\#}$ & $\begin{array}{l}\text { 3-yr: } 48 \%(p<0.001) \\
\text { 5-yr: } 40 \%\end{array}$ & 3-yr: 40\% ( $p<0.001)$ & $\begin{array}{l}3-y r: 72.2 \% \\
(p<0.001) \\
5-y r: 65.4 \%\end{array}$ & $\begin{array}{l}\text { 3-yr: 74\% } \\
(p<0.0001)\end{array}$ & $\begin{array}{l}\text { 3-year: } 78.2 \% \\
(p=0.0862)^{\S \S}\end{array}$ & $\begin{array}{l}\text { 3-yr: 59\% 5-yr: } \\
45.2 \%(p=0.029)\end{array}$ \\
\hline DFS in control arm $^{\#}$ & $3-y r: 31 \%(p<0.001)$ & 3-yr: 24\% $(p<0.001)$ & $\begin{array}{l}3 \text {-yr: } 59.6 \% \\
(p<0.001) \\
5 \text {-year: } 53.1 \%\end{array}$ & $\begin{array}{l}3 \text {-yr: 59\% } \\
(p<0.0001)\end{array}$ & $\begin{array}{l}\text { 3-year: } 74.2 \% \\
(p=0.0862)^{\S \S}\end{array}$ & $\begin{array}{l}\text { 3-yr: 47\% 5-yr: } \\
35.8 \%(p=0.029)\end{array}$ \\
\hline $\begin{array}{l}\text { Grade 3-4 hematologic } \\
\text { events in CRT/CT arm }\end{array}$ & $\begin{array}{l}\text { Hematologic events: } 54 \% ; \\
\text { most common: leukopenia; } \\
\text { no further details specified }\end{array}$ & $\begin{array}{l}\text { Leukopenia: } \\
\text { 11.5\% Neutropenia: } \\
\text { 27.8\% Lymphopenia: } \\
\text { 19.9\% Thrombopenia: 3\% }\end{array}$ & $\begin{array}{l}\text { Leukopenia: } 1.2 \% \\
\text { Neutropenia } \\
\text { and Lymphopenia } \\
\text { unspecified } \\
\text { Thrombopenia: } 0.2 \%\end{array}$ & $\begin{array}{l}\text { Leukopenia: } \\
\text { unspecified } \\
\text { Neutropenia: 22\% } \\
\text { Lymphopenia: } \\
\text { unspecified } \\
\text { Thrombopenia: 8\% }\end{array}$ & $\begin{array}{l}\text { Leukopenia: } \\
\text { unspecified } \\
\text { Neutropenia: } \\
\text { 48.5\% Lymphopenia: } \\
\text { unspecified } \\
\text { Thrombopenia: 0.9\% }\end{array}$ & $\begin{array}{l}\text { Leukopenia: } 7.5 \% \\
\text { Neutropenia and } \\
\text { Lymphopenia } \\
\text { unspecified } \\
\text { Thrombopenia: } 0 \%\end{array}$ \\
\hline $\begin{array}{l}\text { Grade 3-4 hematologic } \\
\text { events in control }{ }^{\neq} \text {arm }\end{array}$ & Unspecified & Unspecified & $\begin{array}{l}\text { Leukopenia: } 0.4 \% \\
\text { Thrombopenia: } 0.4 \%\end{array}$ & $\begin{array}{l}\text { Leukopenia: } \\
\text { unspecified } \\
\text { Neutropenia: } \\
<1 \% \text { Thrombopenia: 0\% }\end{array}$ & $\begin{array}{l}\text { Leukopenia: } \\
\text { unspecified } \\
\text { Neutropenia: 40.7\% } \\
\text { Thrombopenia: 0\% }\end{array}$ & $\begin{array}{l}\text { Leukopenia: } 7.3 \% \\
\text { Neutropenia: } \\
\text { unspecified } \\
\text { Thrombopenia: 0\% }\end{array}$ \\
\hline
\end{tabular}


Table 1 Patient characteristics, side effects and survival in different gastric cancer trials (Continued)

\begin{tabular}{|c|c|c|c|c|c|c|}
\hline $\begin{array}{l}\text { Most common grade 3-4 } \\
\text { non-hematologic events } \\
\text { in CRT/CT arm }\end{array}$ & $\begin{array}{l}\text { Gastrointestinal: } \\
\text { 33\% Influenza-like: } \\
9 \% \text { Infection: } 6 \%\end{array}$ & $\begin{array}{l}\text { Nausea: } \\
\text { 12.3\% Vomiting: } \\
\text { 10.1\% Stomatitis: } 4.3 \%\end{array}$ & $\begin{array}{l}\text { Anorexia: } 6 \% \\
\text { Nausea: } 3.7 \% \\
\text { Diarrhea: } 3.1 \%\end{array}$ & $\begin{array}{l}\text { Nausea: } 8 \% \\
\text { Vomiting: } 7 \% \\
\text { Decreased } \\
\text { appetite: } 5 \%\end{array}$ & $\begin{array}{l}\text { Nausea: } 12.3 \% \\
\text { Vomiting: } \\
\text { 3.1\% Hand-foot } \\
\text { syndrome: } 3.1 \%\end{array}$ & $\begin{array}{l}\text { Nausea: } 2.7 \% \\
\text { Vomiting: } 1.6 \% \\
\text { Diarrhea: } 1.6 \%\end{array}$ \\
\hline $\begin{array}{l}\text { Most common grade 3-4 } \\
\text { non-hematologic events } \\
\text { in control }{ }^{\ddagger} \text { arm }\end{array}$ & Unspecified & Unspecified & $\begin{array}{l}\text { Anorexia: } 2.1 \% \\
\text { Vomiting: } 1.9 \% \\
\text { Nausea: } 1.1 \%\end{array}$ & $\begin{array}{l}\text { Each single } \\
\text { event }<1 \%\end{array}$ & $\begin{array}{l}\text { Nausea: } 12.4 \% \text { Vomiting: } \\
\text { 3.5\% Hand-foot } \\
\text { syndrome: } 2.2 \%\end{array}$ & $\begin{array}{l}\text { No grade } 3-4 \\
\text { non-hematologic } \\
\text { toxicities in CT } \\
\text { group }\end{array}$ \\
\hline
\end{tabular}

* D2 resection in 10\% of patients, D1 in 36\%, and D0 in 54\% of patients; curative resection was inclusion criterion; radiotherapy was conventional $2 \mathrm{~d}$ therapy.

† Patients that did not receive D2 resection were D1-, D0 or non-curatively resected; R0 resection was achieved in $69.3 \%$ of patients in CT arm and in $66.4 \%$ in surgery only arm.

$\S$ XP: capecitabine and cisplatin; in the CRT group, 2 cycles XP were administered, followed by CRT: 45Gy in 1.8Gy fractions, concomitant capecitabine, followed by another 2 cycles of XP.

$\S \S$ In a subgroup analysis of $396 \mathrm{~N}+$ patients, there was a significant prolongation in DFS in the adjuvant CRT arm as compared to the adjuvant CT arm: 3-year DFS 77.5\% vs. $72.3 \%$; $p=0.0365$.

+ In INT-0116, MAGIC, ACTS-GC and CLASSIC control arm was surgery only; in ARTIST trial and Zhu 2012 trial adjuvant CT without radiotherapy was considered as control arm and adjuvant CRT as CT/CRT arm.

¥¥ Patient populations between INT-0116 and MAGIC should be compared in control groups only; the treatment group in MAGIC refers to patients who received CT before surgery and were therefore staged down.

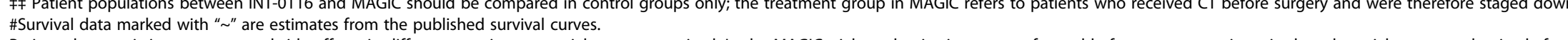

Patient characteristics, outcome and side effects in different gastric cancer trials are summarized. In the MAGIC trial, randomization was performed before surgery; patients in the other trials were randomized after

curative surgery had been peformed. The method of randomization after surgery in the INT-01i6 trial and the low rate of curative resections in the MAGIC trial distort any direct comparison of results between these

landmark trials. The ARTST trial and the Chinese trial by Zhu et al. compare CT to CRT in an adjuvant setup of gastric cancer patients. In the ARTIST trial, an improved DFS by CRT as compared to CT was demonstrated

in trend in the who population; this obsenvalion

inconsistency most probably being due to the more advanced patients in the Chinese trial. A direct comparison in terms of AJCC stage between ARTIST and the trial by Zhu et al. is not possible as in the ARTIST trial, patients were staged according to the $6^{\text {th }}$ AJCC staging system; Zhu and coworkers reported patient classification according to the $7^{\text {th }}$ AJCC staging system. 


\section{(Neo-) adjuvant approaches vs. surgery alone - first evidence on GEJ- and gastric carcinoma patients}

Discussions about therapeutic approaches in addition to surgery in gastric and GEJ carcinoma patients have emerged since the first trial in a randomized setting, US intergroup study (INT)-0116 [27] demonstrated a significant improvement in OS and disease free survival (DFS) in patients with advanced gastric and junctional (20\%) cancer with adjuvant radiochemotherapy (CRT) vs. surgery alone. This study was heavily criticized due to the high rate of D0 dissections (see Table 1 for details); however, benefits on OS of the experimental arm of the INT-0116 treatment protocol were soon confirmed in a non-randomized trial on a population of D2resected Eastern patients by Kim et al. [28], and extended to other CRT protocols by further randomized trials as detailed below. Recently, an update of the INT0116 trial showed that results remained stable in the long term [29]. The authors additionally provided information on the risk of secondary malignancies in the treatment arm. Although they observed a higher incidence of second tumors in the CRT arm, Smalley et al. consider this being biased by: 1 . improved survival in the CRT arm, and: 2. completeness of reporting for second primaries in the treatment arm. Therefore, it seems reasonable to conclude that benefits of CRT outweighed the risk of second malignancies in this setting $[29,30]$.

In contrast to the INT-0116 study, three randomized trials on Western patients, randomized to adjuvant CT with different therapeutic regimens (but without radiation) vs. surgery alone failed to significantly increase survival in stomach cancer [31-33]. Despite the disappointing results on adjuvant CT, Cunningham et al. demonstrated the superiority of perioperative CT vs. surgery alone. The authors enrolled a mixed population of gastric (74\%), GEJ (15\%) and esophageal (11\%) cancer patients in the Medical Research Council Adjuvant Gastric Cancer Infusional Chemotherapy (MAGIC) study [34].

Patients were randomized to surgery alone vs. perioperative CT with ECF, a combination of fluorouracil (FU), cisplatin and epirubicin, administered as described in Table 1. The MAGIC trial was the first to convincingly demonstrate a survival benefit using $\mathrm{CT}$ in Western gastric carcinoma patients. Nevertheless, it has been criticized for similar reasons as the INT-0116 trial: the majority of patients received potentially insufficient lymphadenectomy (see Table 1). Therefore some authors argued that CRT or perioperative CT only compensated for inadequate surgery [35]. In addition, many authors have criticized the MAGIC trial for the persistence of methodological biases related to poor staging accuracy [36], heterogeneity of tumors included, as well as the lack of quality control in the surgical approaches [35,37]. Based on the results of the MAGIC study, perioperative
CT has been widely adopted and included in guidelines [38] in Europe while CRT as performed in INT-0116 trial represents the therapy standard in most centers in the US [39].

A detailed comparison of the INT-0116 study and the MAGIC trial is provided in Table 1; this comparison shows that OS in INT-0116 was about $42 \%$ after five years in the CRT arm while $36.3 \%$ of patients were alive after three years in the MAGIC study. The survival advantage of INT-0116 vs. MAGIC was coherent in terms of DFS, and was despite the fact that: 1. patients had more advanced carcinomas in INT-0116 trial (see Table 1), and: 2. patients in the MAGIC trial received D2 resection in $>40 \%$ of cases vs. $10 \%$ in INT- 0116 . On the other hand, by study design, patients included in INT-0116 trial had already undergone curative resection at randomization. Patients in the MAGIC trial were randomized before any treatment. Cunningham et al. reported that surgery "considered curative by the operating surgeon" was performed in $69.3 \%$ of patients in the CT arm, and $66.4 \%$ in control arm [34]. To our best knowledge, the exact rate of R0, R1 and R2 resections has never been reported by the authors, nonetheless the rate of $69.3 \%$ was recognized by some authors as R0 resection rate in the MAGIC trial $[29,40,41]$. According to a statement taken from personal communication published by Smalley et al. in their update on the INT-0116 trial, D. Cunningham stated that R1 resection was especially common in the GEJ carcinomas [29].

The differences in study design between both trials must be emphasized as they hamper any reasonable comparison and explain the worse OS in the control arm of the MAGIC trial (as compared to INT-0116) despite the higher rate of D2 resections performed in the study population.

Therefore a direct comparison between MAGIC and INT-0116 is not possible. This explains the many different interpretations in the literature and the different therapeutic approaches after publication of the MAGIC trial in the US and in Europe.

\section{Confirmation of survival advantages by adjuvant $\mathrm{CT}$ vs. surgery alone in D2-dissected gastric cancer patients} While the superiority of CRT / CT vs. surgery alone in Western trials might be due to inadequate surgery, this is certainly not the case in studies on Eastern populations. As already mentioned, Kim et al. [28] confirmed the survival advantage of adjuvant CRT in a nonrandomized population of D2-dissected patients.

In addition, the advantage of adjuvant therapeutic regimens vs. surgery alone was confirmed by Eastern randomized trials. First, Sakuramoto and coworkers reported on S-1 (TS-1), an orally active combination of tegafur, gimeracil, and oteracil. The authors reported in the 
Adjuvant Chemotherapy Trial of TS-1 for Gastric Cancer (ACTS-GC) on 1059 randomly assigned patients with gastric carcinoma who underwent D2 surgery with or without adjuvant S-1 [42]. In accordance with the other trials they found a significant increase in OS and DFS [43] (see Table 1 for details). Nakajima et al. reported on 190 early stage gastric carcinoma patients (T2N1-2) randomized to adjuvant uracil-tegafur or surgery alone [44]. All patients received extended lymph node resection and both OS and DFS were significantly better in the CT group (HR 0.46, 13\% difference in survival at 4 years).

The latest Eastern results were provided by the capecitabine and oxaliplatin adjuvant study in stomach cancer (CLASSIC), 1035 patients in South Korea, China, and Taiwan were randomized to adjuvant CT vs. surgery only [45]. The difference in 3-year OS was minor compared to other studies $(83 \%$ vs. $78 \%, \mathrm{p}=0.0493)$, nevertheless there was a significant and considerable difference in DFS; details are provided in Table 1.

\section{Therapeutic approaches in GEJ carcinoma patients - changes in treatment approaches during the last years} In the last years, therapeutic approaches on GEJ carcinoma patients were essentially based on results derived from the INT-0116 [27] and the MAGIC [34] trial. Standard of care in the US was mainly adjuvant CRT as described in the intergroup protocol while European oncologists and surgeons preferred the perioperative CT as described in the MAGIC protocol [46]. However, given the shortcomings of both, the low proportion of GEJ carcinoma patients included, and the current discussion about a closer relation of GEJ to esophageal carcinoma [17], it is now time to reconsider therapeutic strategies for GEJ tumors. This applies even more as evidence shows that adjuvant therapeutic strategies (CT and CRT) in esophageal carcinoma patients have led to disappointing results [47-50].

In contrast to the results in gastric carcinoma, neoadjuvant regimens seem to surpass adjuvant strategies in esophageal carcinoma patients [51]. Recently, more evidence for neoadjuvant treatments was provided by the OEO2 trial [52] which showed a significant survival benefit (5-year OS $23 \%$ vs. $17.1 \%$; $\mathrm{p}=0.003$ ) with neoadjuvant $\mathrm{CT}$ and surgery vs. surgery alone, nevertheless a similar trial in the US (RTOG trial 8911, US Intergroup113) could not demonstrate a survival advantage [53].

Notwithstanding these contradictory results in single trials, meta-analyses $[51,54,55]$ clearly indicate survival benefits of neoadjuvant CRT and CT regimens as compared to surgery alone in locally advanced esophageal and GEJ carcinoma. When interpreting these findings, it must be considered that the mentioned analyses include a majority of esophageal SCC $[47-51,54,55]$, therefore there is still an ongoing discussion which results and therapeutic approaches may be extrapolated on GEJ adenocarcinoma [41]. A trial reported by Walsh et al. in 1996 strongly suggested a superiority of neoadjuvant CRT and surgery vs. surgery alone in patients with (only) adenocarcinoma of the GEJ, the esophagus or the cardia. The authors randomized 113 patients with adenocarcinoma of the GEJ, the esophagus, or the cardia to neoadjuvant CRT (40Gy + FU + Cisplatin) and surgery vs. surgery alone [56]. Multimodal therapy resulted in significantly improved OS vs. surgery alone (median survival in CRT and surgery arm was 16 months, as compared with 11 months in the surgery only arm; $\mathrm{p}=0.01$ ).

In essence, therapeutic approaches in GEJ carcinoma patients have recently been dominated by the protocols of the two landmark trials (INT-0116 and MAGIC). Although there was evidence in favor of neoadjuvant regimens, similar to esophageal therapeutic strategies, patients with GEJ adenocarcinoma were treated either perioperatively or with an adjuvant approach. The basic question if radiation therapy in addition to surgery and chemotherapy should be applied in GEJ- and in gastric cancer therapy has therefore been raised again by recent results.

\section{Latest results and new evidence suggesting a benefit of radiation therapy in addition to neoadjuvant, adjuvant or perioperative chemotherapy in GEJ patients}

As mentioned above, meta-analyses showed neoadjuvant therapy to improve OS compared with surgery alone for esophageal cancer, including GEJ. A benefit for neoadjuvant CRT vs. CT alone has been suggested but was not clearly demonstrated [51].

In the discussion about CRT vs. CT as a neoadjuvant therapy, evidence in favor of CRT has emerged during the last years. A phase III trial conducted by Stahl et al. who compared a total of 126 patients receiving either neoadjuvant CT followed by surgery or neoadjuvant CRT followed by surgery [57]. Although the study was closed early and differences were not statistically significant, results showed a statistical trend to a survival advantage for CRT as compared to CT in GEJ adenocarcinoma (3-year OS $27.7 \%$ vs. $47.4 \%$, for details see Table 2 ). Another recently published study is the ACCORD07 phase III trial [58]; the authors reported on a significantly improved survival by $\mathrm{CT}$ without irradiation as compared to surgery alone, their regimen was associated with marked general toxicity (see Table 3 for comparison) their survival rates also being worse than reported by other recently reported CRT trials in comparable populations (see Table 2). Strong evidence in favor of neoadjuvant CRT was provided by van Hagen and coworkers. The authors recently reported on 368 patients with esophagus and junctional carcinoma in the CROSS trial [59]. Patients with T1N+ or T2-T3N0-1 
Table 2 Patient characteristics and survival in GEJ carcinoma trials

\begin{tabular}{|c|c|c|c|}
\hline Clinical Trial & ACCORD07 & CROSS & Stahl 2009 \\
\hline $\begin{array}{l}\text { Number of } \\
\text { patients } \\
\text { randomized }\end{array}$ & 224 & 368 & 126 \\
\hline Histology & Adenocarcinoma: 100\% & $\begin{array}{l}\text { Adenocarcinoma: } \\
\text { 75\%; SCC: } 23 \% \text {; } \\
\text { other: } 2 \%\end{array}$ & Adenocarcinoma: $100 \%$ \\
\hline Tumor location & $\begin{array}{l}\text { Distal esophagus: } 11 \% ; \\
\text { GEJ: 64\%; stomach: } 25 \%\end{array}$ & $\begin{array}{l}\text { Esophagus }^{+} \text {: 73\%; } \\
\text { GEJ: 24\%; Unspecified: 3\% }\end{array}$ & $\begin{array}{l}\text { 100\% GEJ Siewert I: 55\%, } \\
\text { Siewert II/III: } 45 \%\end{array}$ \\
\hline Treatment in CT/CRT arm & $\begin{array}{l}\text { Cisplatin and } \mathrm{FU}^{\S} \text { in } \\
\text { perioperative combination } \\
\text { with surgery }\end{array}$ & $\begin{array}{l}\text { Neoadjuvant carboplatin } \\
\text { \& paclitaxel with concurrent } \\
\text { 41.8/1.8Gy, followed by surgery }\end{array}$ & $\begin{array}{l}\text { Neoadjuvant PLF", followed by } \\
\text { cisplatin \& etoposide with } \\
\text { concurrent } 30 / 2 \mathrm{~Gy} \text {, } \\
\text { followed by surgery }\end{array}$ \\
\hline Treatment in control arm $^{\neq}$ & Surgery only & Surgery only & $\mathrm{PLF}^{\#}$, followed by surgery \\
\hline TNM in CT/CRT arm $^{*}$ & $\begin{array}{l}\text { T0: 3\%; T1-2: 39\%; } \\
\text { T3-4: 58\%; N0: 33\%; } \\
\text { N+: 67\%; M0: 99\%; M1: 1\% }\end{array}$ & $\begin{array}{l}\text { T1-2: 16\%; T3-4: 84\%; } \\
\text { unspecified T: } 1 \% ; \\
\text { N0: 33\%; N+: 65\%; } \\
\text { unspecified N: } 2 \%\end{array}$ & $\begin{array}{l}\text { T1-2: 0\%; T3: 92\%; T4: 8\%; } \\
\text { N0: 64\%; N+: 36\% }\end{array}$ \\
\hline TNM in control arm $^{*}$ * & $\begin{array}{l}\text { T1-2: 32\%; T3-4: 68\%; } \\
\text { N0: 20\%; N+ 80\%; } \\
\text { M0: } 93 \% ; M 1: 7 \%\end{array}$ & $\begin{array}{l}\text { T1-2: 20\%; T3-4: 79\%; } \\
\text { unspecified T: } 2 \% ; \\
\text { N0: 31\%; N+: 64\%; } \\
\text { unspecified N: } 5 \%\end{array}$ & $\begin{array}{l}\text { T1-2: 0\%; T3: 92\%; T4: 8\%; } \\
\text { N0: 37\%; N+: 63\% }\end{array}$ \\
\hline OS in CT/CRT arm & 5-year: $38 \%(p=0.02)^{\dagger}$ & $\begin{array}{l}\text { 5-year: } 47 \% ; 3 \text {-year: } 58 \% ; \\
\text { median: } 49.4 \text { months }(p=0.003)^{+}\end{array}$ & $\begin{array}{l}\text { Median: 33.1months; } \\
\text { 3-year: } 47.4 \%(p=0.07)^{+}\end{array}$ \\
\hline OS in control arm & 5-year: $24 \%(p=0.02)^{\dagger}$ & $\begin{array}{l}\text { 5-year: 34\%; 3-year: } 44 \% ; \\
\text { median: } 24 \text { months }(p=0.003)^{\dagger}\end{array}$ & $\begin{array}{l}\text { Median: } 21.1 \text { months } \\
\text { 3-year: } 27.7 \%(p=0.07)^{+}\end{array}$ \\
\hline DFS in CT/CRT arm & 5 -year: $34 \%(p=0.003)^{\dagger}$ & $\begin{array}{l}\text { Median DFS not } \\
\text { reached }(p<0.001)^{\dagger}\end{array}$ & $\begin{array}{l}\text { 3-Y: } 41.3 \%(P \text { not significant, } \\
\text { value not reported) }\end{array}$ \\
\hline DFS in control arm $^{\neq}$ & 5 -year: $19 \%(p=0.003)^{\dagger}$ & $\begin{array}{l}\text { Median DFS } 24.2 \\
\text { months }(p<0.001)^{\dagger}\end{array}$ & $\begin{array}{l}\text { 3-Y: } 24.9 \%(P \text { not significant, } \\
\text { value not reported) }{ }^{\dagger}\end{array}$ \\
\hline $\begin{array}{l}\text { Postoperative } \\
\text { mortality in } \\
\text { CT/CRT arm }\end{array}$ & $4.6 \%(p=0.76)^{\dagger}$ & $\begin{array}{l}4 \%(\mathrm{P} \text { not significant, } \\
\text { value not reported) }{ }^{\dagger}\end{array}$ & $10.2 \%(p=0.26)^{\dagger}$ \\
\hline $\begin{array}{l}\text { Postoperative } \\
\text { mortality in } \\
\text { control } \text { arm }^{\neq}\end{array}$ & $4.5 \%(p=0.76)^{\dagger}$ & $\begin{array}{l}4 \%(P \text { not significant, } \\
\text { value not reported })^{\dagger}\end{array}$ & $3.8 \%(p=0.26)^{\dagger}$ \\
\hline $\begin{array}{l}\text { Ro resection } \\
\text { rate in CT/CRT arm }\end{array}$ & $84 \%(p=0.04)^{\dagger}$ & R0: $92 \%(p<0.001)^{\dagger}$ & $\begin{array}{l}\text { 72\% (P not significant, } \\
\text { value not reported) }\end{array}$ \\
\hline $\begin{array}{l}R 0 \text { resection } \\
\text { rate in control arm }\end{array}$ & $74 \%(p=0.04)^{\dagger}$ & R0: $69 \%(p<0.001)^{\dagger}$ & $\begin{array}{l}\text { 69\% (P not significant, } \\
\text { value not reported) }{ }^{\dagger}\end{array}$ \\
\hline $\begin{array}{l}\text { Complete response } \\
\text { in } C T / C R T \text { arm }\end{array}$ & Unspecified & $\begin{array}{l}29 \% \text { (23\% in adenocarcinoma } \\
\text { patients, } 49 \% \text { in SCC patients) }\end{array}$ & $15.6 \%(p=0.03)^{\dagger}$ \\
\hline $\begin{array}{l}\text { Complete response } \\
\text { in control } \text { arm }^{\ddagger}\end{array}$ & - & - & $2 \%(p=0.03)^{\dagger}$ \\
\hline $\begin{array}{l}\text { Tumor free } L N \\
\text { at time of surgery } \\
\text { in } C T / C R T \text { arm }\end{array}$ & $33 \%(p=0.054)^{\dagger}$ & $69 \%(p<0.001)^{\dagger}$ & $64 \%(p=0.01)^{\dagger}$ \\
\hline $\begin{array}{l}\text { Tumor free } L N \\
\text { at time of surgery } \\
\text { in control } \text { arm }^{\neq}\end{array}$ & $20 \%(p=0.054)^{\dagger}$ & $25 \%(p<0.001)^{\dagger}$ & $37 \%(p=0.01)^{\dagger}$ \\
\hline
\end{tabular}

+ Locations of esophageal carcinomas were further specified as follows: proximal third: 2\%; middle third: 13\%; distal third 58\%.

\# Control arm in ACCORD07 and CROSS was surgery only; Stahl 2009 had no surgery only arm, we considered CT without radiotherapy as control arm in this table.

$\S$ FU: fluorouracil.

\# PLF: cisplatin, fluorouracil, and leucovorin

* TNM in ACCORD07 is pathologically (pTNM) staged; TNM in CROSS is clinically (CTNM) by means of endoscopic ultrasonography, computed tomography (CT), or ${ }^{18} \mathrm{~F}$-fluorooxyglucose positron-emission tomography; TNM in Stahl 2009 is clinically for T-staging (uT), but pathological for N-staging.

† All mentioned p-values refer to comparison of the specified factor between CT/CRT arm, and control arm.

Patient characteristics and outcome of patients with GEJ- and esophageal carcinoma; in ACCORD07 and CROSS trial, surgery only arm was regarded as control arm; in Stahl 2009, neoadjuvant PLF without irradiation followed by surgery was considered control arm while neoadjuvant CRT was considered CT/CRT arm. 
Table 3 Comparison of toxicity and side effects in different GEJ carcinoma trials

\begin{tabular}{|c|c|c|c|}
\hline Clinical Trial & ACCORD07 & CROSS & Stahl 2009 \\
\hline $\begin{array}{l}\text { Number of patients } \\
\text { randomized }\end{array}$ & 224 & 368 & 126 \\
\hline $\begin{array}{l}\text { Patients with at } \\
\text { least grade } 3 \text { toxicity }\end{array}$ & $38 \%$ & $\begin{array}{l}\text { Hematologic: } 7.6 \% \\
\text { All other: } 13 \%\end{array}$ & Unspecified \\
\hline $\begin{array}{l}\text { Grade } 3 \text { - and } \\
4 \text { toxicity in control arm }\end{array}$ & - & - & $5 \%$ (CT arm as control arm) \\
\hline $\begin{array}{l}\text { Grade 3-4 leukopenia } \\
\text { during } C T / C R T\end{array}$ & $5.5 \%$ & $6 \%$ & $12 \%$ \\
\hline $\begin{array}{l}\text { Grade 3-4 neutropenia } \\
\text { during } C T / C R T\end{array}$ & $20.2 \%$ & $2 \%$ & unspecified \\
\hline $\begin{array}{l}\text { Grade 3-4 thrombocytopenia } \\
\text { during CT/CRT }\end{array}$ & $5.5 \%$ & $1 \%$ & $5 \%$ \\
\hline $\begin{array}{l}\text { Progressive disease during } \\
\text { preoperative therapy }\end{array}$ & $11 \%$ & $\begin{array}{l}\text { Absolute number unspecified; } \\
7 \text { patients ( } 4 \% \text { ) did not undergo } \\
\text { surgery because of disease progression }\end{array}$ & $10 \%$ \\
\hline Deaths during $C T / C R T$ & $1 \%$ & $1 \%$ & $\begin{array}{l}\text { One patient (2\%) died in CT group; } \\
\text { none died in CRT group }\end{array}$ \\
\hline
\end{tabular}

Side effects and toxicity in GEJ carcinoma trials; in CROSS- and ACCORD07 trial, surgery only was defined as control arm; in Stahl 2009, CT arm was considered as control arm, CRT was considered as CT/CRT arm.

tumors were included, the majority presenting with adenocarcinoma of the distal or junctional esophagus. Patients were randomly assigned to CRT followed by surgery, and to surgery alone. CRT consisted of carboplatin and paclitaxel as well as a total radiation dose of 41.4Gy given in 23 fractions of $1.8 \mathrm{~Gy}$ each. The planning target volume (PTV) included the primary tumor with radial margins of $1.5 \mathrm{~cm}$ and proximal and distal margins of 4 $\mathrm{cm}$. In addition, any enlarged lymph nodes were included. If the tumor extended into the stomach, a distal margin of $3 \mathrm{~cm}$ was chosen; further details are summarized in Table 2. Patients underwent surgery after CRT as soon as possible (median time: 6.6 weeks), and patients in the surgery group were treated as soon as possible after randomization. Interestingly, the authors found no significant difference in surgical complications or postoperative mortality between CRT and surgery only groups. Surgeons achieved significantly more R0 resections in the CRT group as compared to the surgery only group (92\% vs. $69 \%$; $<0.001)$. After completion of a median follow-up time of 45.4 months for surviving patients, an intention to treat analysis showed a median OS of 49.4 months in the CRT arm vs. 24.0 months in the surgery only group (for details see Table 2). These results are markedly better than those achieved by other therapeutic approaches. The authors reported that the survival difference was significant for all histological subgroups and the benefit of CRT was consistent across subgroups without any significant interaction identified. Toxicity of CRT was very low in terms of hematologic and non-hematologic side effects (see Table 3 for details).

In summary, recent data in GEJ carcinoma indicate a survival benefit of neoadjuvant CRT and CT in curatively resectable patients. Due to a trend for better survival of CRT vs. CT as reported by Stahl and coworkers and because of the substantially longer survival reported in the CROSS trial, CRT as performed in the CROSS trial should be considered as a standard treatment of patients with potentially curatively resectable GEJ carcinoma in tumor stages $>$ T1N0.

\section{Latest data on therapeutic approaches in gastric carcinoma - new evidence for adjuvant CRT vs. perioperative $\mathrm{CT}$}

Recent trials in Eastern populations include the already mentioned CLASSIC trial which demonstrated in a large population in South Korea, China, and Taiwan, that capecitabine and oxaliplatin in an adjuvant setting after D2 gastrectomy is significantly associated with longer DFS when compared to surgery alone (see Table 1). In another Eastern population, Lee et al. conducted the ARTIST trial to compare CT vs. CRT; the concept being similar to the above mentioned Stahl trial, which was conducted in GEJ, to demonstrate superiority of CRT and surgery vs. CT and surgery in gastric carcinoma [60]. Although DFS was not significantly increased by CRT vs. CT, the authors observed a statistical trend to better DFS with CRT (78.2\% vs. $74.2 \%$ after 3 years). In a subgroup analysis of patients with positive pathologic nodes, the advantage on DFS for CRT vs. CT was significant; after three years, a difference of 5\% more diseasefree patients was achieved by adjuvant CRT as compared to CT ( $\mathrm{p}=0.0471$; details are summarized in Table 1 ).

Although subgroup analyses should be interpreted with caution, the high number of patients provides in our opinion sufficient power in favor of adjuvant CRT in patients with positive lymph nodes. For the whole population in the ARTIST trial, it must be taken into account that 
survival curves crossed after about 24 months. This indicates that better local tumor control by CRT as compared to CT outweighs toxic effects only after a sufficient observation time. After three years there are still a considerable number of patients at risk for relapse; so effects on tumor control might lack significance in this early analysis as compared to long-term observations. The secondary endpoint (OS) was not (yet) analyzed by the authors due to a low number of events [60]. The acute toxicity profile of both arms was comparable with only slightly more grade 3 neutropenia in the CRT arm and a higher rate of patients with grade $2-3$ hand-foot syndrome in the CT group (13.7\% vs. $10.6 \%$; see Table 1 for further details). On the basis of these data, the ARTIST-2 trial was proposed that should compare CT vs. CRT in patients with nodepositive gastric cancer [60].

Interestingly, Zhu et al. recently reported on a similar trial conducted in a Chinese population. As further detailed in Table 1, the authors compared adjuvant CT alone to adjuvant CRT with intensity-modulated radiotherapy (IMRT) in a randomized setting consisting of 380 curatively D2-resected patients [61]. When compared to Lee et al. (ARTIST; [60]), Zhu and coworkers observed a significant difference in DFS between the therapeutic regimens not only in patients with positive nodes but in the whole population after an observation time of at least five years or until death of the patient.

Although a direct comparison between the populations in terms of TNM-stage is hampered by different staging patterns (AJCC $6^{\text {th }}$ vs. $7^{\text {th }}$ version), it is most likely that the stronger effect on DFS as compared to the ARTIST trial is due to the: 1 . more advanced patients, especially in terms of lymph node involvement; this is also suggested by the increased rate of patients in the Chinese trial as compared to the ARTIST study, who died mainly because of local recurrence (Zhu et al.: $19.7 \%$ vs. ARTIST: $6.6 \%$ or: 2 . the longer observation time, as described above, the observation time in the Korean trial might be relatively short, considering the high number of patients still at risk for relapse.

Both the data provided by the ARTIST trial and by the Chinese study lead to the assumption that gastric carcinoma patients benefit the more from CRT as compared to $\mathrm{CT}$, the more advanced their carcinomas are. This assumption is further supported by a small trial reported by $\mathrm{Yu}$ et al., the authors described in 68 randomly assigned advanced gastric carcinoma patients (T3-4 and/ or $\mathrm{N+}$ ) a significant superiority of adjuvant CRT with 45Gy irradiation applied by IMRT and FU/FA as compared to adjuvant FU/FA only (3-yr OS: $67.7 \%$ vs. $44.1 \%$; $\mathrm{p}=0.037$ ) [62]. Although the collective in this study was supposedly underpowered, results add to the hypothesis that more advanced gastric carcinoma patients benefit from CRT as compared to CT. Additionally the Chinese trials emphasize the need for further implementation of IMRT in radiotherapy of gastric carcinomas.

If these encouraging results can be reproduced in Western populations is undetermined. As mentioned above, there are considerable inconsistencies in terms of clinical results between trials conducted on Western patients and trials on Eastern patients. It is not clear if these differences were caused by differences in tumor biology or by other epidemiological factors.

In Western patients, there are currently no large randomized post-MAGIC results on CRT vs. CT in gastric carcinoma patients; retrospective data provided by Dikken et al. [63] on a European population of 91 gastric cancer patients undergoing CRT even suggested D2dissected patients in this population $(\mathrm{n}=25)$ did not benefit from adjuvant CRT in terms of survival as compared to surgery only. Given this inconsistency with earlier results and the underpowered population size, the authors proposed a large randomized trial to compare CRT vs. perioperative CT in Western patients with gastric cancer. This currently ongoing study is the CRITICS trial (NCT00407186; [40]) which compares perioperative CT (epirubicin, cisplatin, capecitabine; ECC) and surgery, with neoadjuvant $\mathrm{CT}$, followed by surgery and adjuvant CRT (45Gy in 25 fractions; concurrent capecitabine and cisplatin).

Taken together, superiority of CRT vs. CT in gastric carcinoma patients is suggested by Eastern trials, especially for advanced but curatively resectable patients. Nevertheless, the situation is not as clear as in GEJ carcinomas, because perioperative $\mathrm{CT}$ as performed in the MAGIC trial has until now not been compared to CRT in a randomized setup. The most important ongoing trial to address this topic is the CRITICS trial, which is estimated to complete accrual in December 2013.

Given the results of the Korean and the Chinese trials, and the difficult comparison of the INT-0116 and the MAGIC trial, CRT seems to be at least equal to CT in gastric cancer (excluding GEJ carcinoma). In Eastern populations, recent results strongly indicate a longer DFS by CRT as compared to CT in advanced patients (especially $\mathrm{N}+$ ); if these data can be reproduced in Western patients will be clarified by the CRITICS trial. Another reason for the good results of the Chinese trial might be the utilization of IMRT which successively replaces 3D conformal radiotherapy (3DCRT) in gastric and GEJ carcinoma treatment.

\section{Radiotherapy in GEJ and gastric carcinoma - practical considerations, latest technical advances and reduction of side effects by IMRT}

As mentioned above, local recurrence contributes to a worse prognosis in gastric and GEJ carcinoma. External beam radiotherapy (EBRT) in an adjuvant setting for 


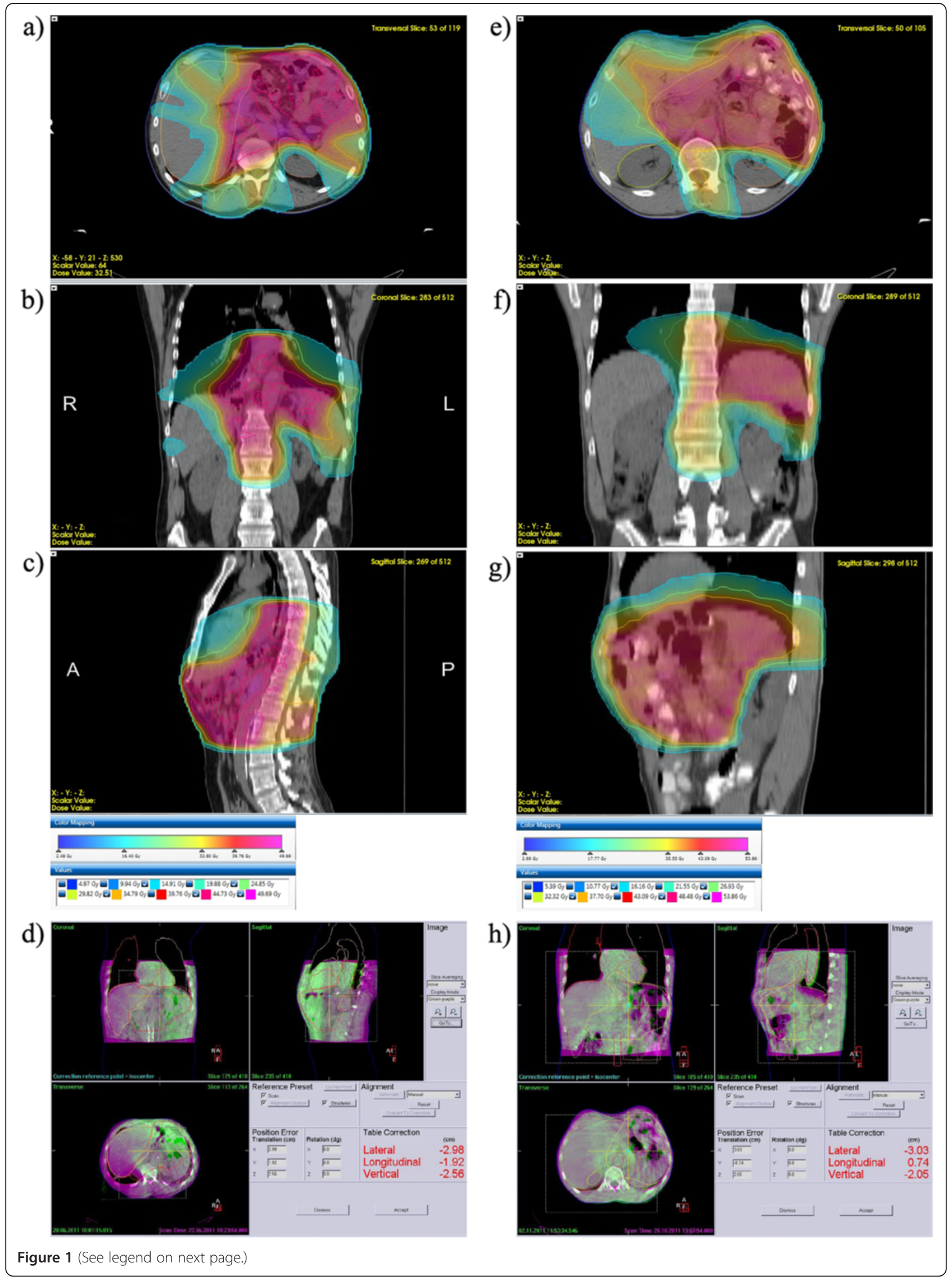


(See figure on previous page.)

Figure 1 VMAT treatment plans for gastric and GEJ carcinomas. (a-c): Volumetric intensity-modulated arc therapy (VMAT) plan (Monaco ${ }^{\circledR}$, Elekta, Crawley, UK) of a patient with a junctional carcinoma in the adjuvant situation. Transversal (a), coronal (b), and sagittal (c) dose distributions. Color wash and isodose lines are indexed in the insert. A total dose of 45Gy was applied. Note the expansion of the planning target volume (PTV) to the distal esophagus and sparing of the posterior wall of the heart, both lungs, and the dorsolateral renal cortex in the left kidney. (d): Cone beam computed tomography (CBCT) based position correction directly before the first therapy fraction after positioning based on skin marks. Magenta: planning computed tomography (PCT); green: CBCT; both PCT and CBCT in mid-ventilation position. Manual position correction was based on internal surrogate structures such as calcifications in the aorta. (e-g): VMAT plan of a patient with stomach (corpus) carcinoma in the adjuvant situation. Transversal (e), coronal ( $f$ ) and sagittal $(\mathrm{g}$ ) dose distributions. Color wash and isodose lines are indexed in the insert. A total dose of 45Gy was applied. Note the sparing of the dorsolateral renal cortex in the left kidney and the complete right kidney. (h): CBCT based position correction directly before the first therapy fraction. Magenta: PCT; green: CBCT.

gastric carcinoma or in a neoadjuvant setup for esophageal and GEJ adenocarcinoma offers the possibility to prevent local relapse if sufficiently large PTVs covering tumor bed, gastric stump, anastomosis and D2-3 lymph node regions [64] are treated [65]. For proximal tumors, the distal part of the esophagus should be included; for corpus/distal tumors [66] diaphragm/proximal duodenum should also be covered.

Fulfillment of these criteria results in a geometrical complex and large upper abdominal PTV in direct vicinity of the liver, both kidneys and spinal cord which may lead to therapy interruption and possible late toxicity. While total dose applied (45-50.4Gy) is below spinal cord tolerance, irradiation of the kidney with ablative doses can cause late renal toxicity which is becoming more and more relevant for long-term survivors [67-69].

With conventional 2D techniques and 3DCRT, definition of the PTV was a compromise between kidney sparing and PTV coverage. PTV size was reduced at the cost of the risk of local relapse, but nevertheless at least the proximal part of most frequently the left kidney had to be irradiated with ablative doses [70,71].

The introduction of IMRT allows steep and concave dose gradients and a highly conformal dose distribution also for large PTVs with complex geometry [72]. The combination of IMRT with image-guided radiotherapy (IGRT) allows the daily precise application of these highly conformal doses. Dosimetric analyses have shown that IMRT can reduce the median kidney

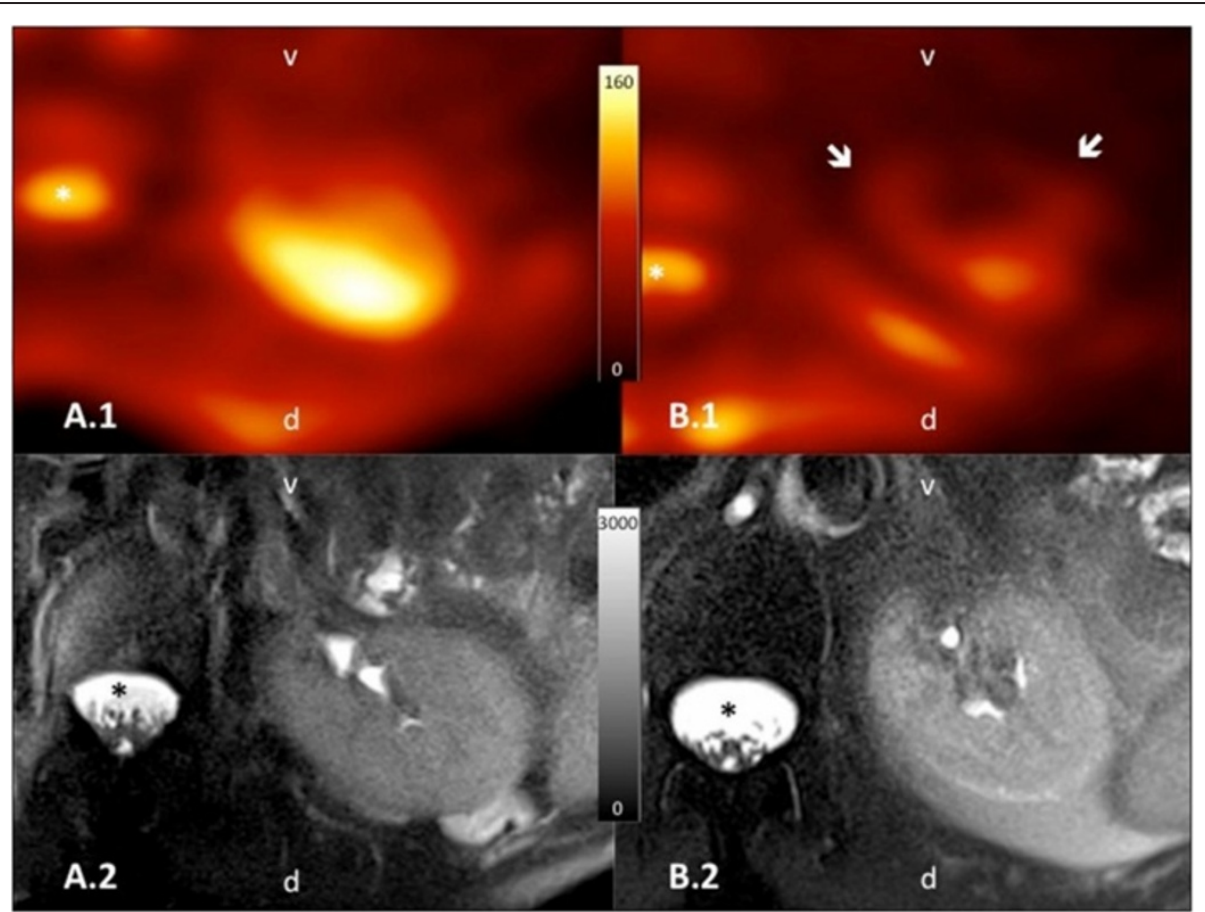

Figure $2{ }^{23} \mathrm{Na}$-images of patients treated with 3DCRT or IMRT. Axial orientated, color-encoded ${ }^{23} \mathrm{Na}$-images (A.1 and B.1) with the corresponding morphological fat-saturated T2-weighted images (A.2 and B.2) of the left kidney. Orientation is given in the images as $v=$ ventral; $\mathrm{d}=$ dorsal and the cerebrospinal fluid (CSF) is marked with an asterisk *. The patient shown in A.1/A.2 was treated with IMRT and the other patient in B.1/B.2 respectively with 3DCRT, both after gastric cancer. Though both morphological images present unremarkable renal parenchyma, functional ${ }^{23} \mathrm{Na}$-images clearly depict a reduced ${ }^{23} \mathrm{Na}$-content (arrows) in the ventral area included in the field of high-dose radiotherapy. 
doses below the tolerance limits [73] despite treating larger PTVs which cover all recommended regions at risk for local relapse [73-75]. IMRT dose distribution within the kidneys is also more favorable if compared to conventional techniques: the functionally most important renal cortex is spared [65,74] (see Figure 1e-h). Additionally even these lower doses are delivered at lower single fractions, which can also have an impact on sparing functional capacity [76]. However this effect has to be investigated by functional imaging and laboratory values in long-term survivor populations. First results with functional MRI have shown intact kidney morphology, diffusion capacity and sodium concentration in long-term survivors of gastric cancer treated by IMRT combined with modern chemotherapy doublets [77]. These results were consistent with the observation that patients retained normal creatinine (and creatinine clearance) levels and did not show any clinical signs of late renal toxicity (see Figure 2 [77]).

In GEJ and esophageal carcinoma treatment, Kole and coworkers reported IMRT to reduce heart- and coronary artery doses as compared to 3DCRT [78]. However, no long-term clinical data are available about outcome in terms of cardiac toxicity of both modalities. In the neoadjuvant setting, IMRT with concurrent CT has also been shown to be well tolerated, accomplished excellent target coverage and normal structure sparing, and led to appropriate response rates [79].

In the last years, modern IMRT techniques such as rotational IMRT (VMAT/IMAT, RapidArc) and helical tomotherapy have been introduced $[80,81]$. Volumetric intensity-modulated arc therapy (VMAT) has the capability to further decrease treatment times (and with that, the impact of intrafractional patient and organ motion on the effectively absorbed dose compared to IMRT while still providing similar PTV coverage and organ at risk sparing. Dosimetric comparisons indicated VMAT to be a favorable treatment option for esophageal and junctional carcinoma [82-86].

Further technical developments such as integrating breath hold in the image-guided workflow can probably further improve dose distribution parameters [87]. Steep dose gradients can be precisely applied by all of these techniques if combined with daily 3D soft-tissue based image-guidance (see Figure 1a-d for GEJ carcinoma and Figure 1e-h for gastric carcinoma; $[88,89])$. For gastric cancer, $\mathrm{kV}$ or $\mathrm{MV}$ cone beam computed tomography (CBCT) or ultrasound based techniques can be both applied [90-93].

Data on radiation therapy of gastric- and GEJ carcinoma with protons are relatively rare. However, as demonstrated by Welsh et al., intensity-modulated proton therapy may be able to further at least theoretically, reduce normal tissue exposure if compared to IMRT in definitive therapy for locally advanced distal esophageal tumors [94].

Clinical results of IMRT compared to 3DCRT regarding outcome and acute and late toxicity profile have been evaluated by some retrospective studies [95,96]; however no large randomized studies exist for gastric cancer. In our own retrospective analysis, adjuvant CRT with IMRT and modern chemotherapy doublets led to better survival of patients with advanced gastric cancer compared to the adjuvant combination of 3DCRT and conventional chemotherapy [95,97], also in the longterm follow-up [98].

A similar comparison of survival and local control after IMRT vs. 3DCRT for esophageal cancer has been completed by Lin et al. on a large retrospective cohort [99]. In this study, OS, local control, and non-cancerrelated death were significantly better with IMRT when compared to 3DCRT [99].

These first results are encouraging, however, large prospective trials and long-term clinical and functional investigations regarding risk organ functions are necessary to evaluate the role of modern radiotherapy techniques for gastric and GEJ carcinoma.

\section{Conclusion}

Recent data in GEJ carcinoma indicate a survival benefit of neoadjuvant CRT in curatively resectable patients. Although there are also data showing an effect of CT in perioperative settings, both the trials by Stahl et al. and the CROSS trial indicate a superiority of neoadjuvant CRT as compared to perioperative CT. Surgery alone without neoadjuvant or perioperative therapy should be regarded suboptimal in these patients. In gastric carcinoma patients, on the other hand, the situation is different as perioperative CT has not been compared to adjuvant CRT in a randomized setting. In Asia, as suggested by the results of the recently published ARTIST trial and the Chinese data by Zhu and coworkers, CRT is significantly superior in terms of DFS as compared to adjuvant $\mathrm{CT}$ in advanced gastric carcinoma patients (especially $\mathrm{N}+$ patients). Reliable conclusions about which therapy should be preferred in Western patients will be provided by the ongoing CRITICS trial. If radiotherapy is performed, modern approaches such as IMRT and image guidance should be applied, as these methods reduce dose to organs at risk and provide a more homogenous coverage of PTVs.

\section{Abbreviations}

3DCRT: 3D conformal radiotherapy; ACTS-GC: Adjuvant Chemotherapy Trial of TS-1 for Gastric Cancer; AJCC: American Joint Committee on Cancer; ARTIST: Adjuvant Chemoradiation Therapy in Stomach Cancer; CBCT: Cone beam computed tomography; CLASSIC: Capecitabine and oxaliplatin adjuvant study in stomach cancer; CRITICS: Chemoradiotherapy after Induction Chemotherapy in Cancer of the Stomach; CT: Chemotherapy; 
CRT: Radiochemotherapy; CSF: Cerebrospinal fluid; DFS: Disease free survival; FU: Fluorouracil; EBRT: External beam radiotherapy; ECC: Epirubicin, cisplatin, and capecitabine; GEJ: Gastroesophageal junction; IGRT: Image-guided radiotherapy; INT-0116: US intergroup trial 0116; JGCA: Japanese Gastric Cancer Association; MAGIC: Medical Research Council Adjuvant Gastric Cancer Infusional Chemotherapy; OS: Overall survival; MRI: Magnetic resonance imaging; PCT: Planning computed tomography; PTV: Planning target volume; RTOG: Radiation Therapy Oncology Group; S-1 / TS-1: An orally active combination of tegafur, gimeracil, and oteracil; SCC: Squamous cell carcinoma; VMAT: Volumetric intensity-modulated arc therapy.

\section{Competing interests}

The authors declare that there are no competing interests.

\section{Authors' contributions}

$\mathrm{DB}, \mathrm{FL}, \mathrm{FW}$, and JBH have drafted the manuscript; $\mathrm{TB}, \mathrm{KS}, \mathrm{SH}$ and $\mathrm{HM}$ provided figures and legends. All authors read and approved the final manuscript.

\section{Acknowledgements}

JBH is supported by the Ministerium fuer Bildung und Forschung, BadenWuerttemberg and the European Social Fonds (ESF).

\section{Author details}

'Department of Radiation Oncology, Universitätsmedizin Mannheim, Medical Faculty Mannheim, Heidelberg University, Mannheim, Germany. ${ }^{2}$ Institute of Clinical Radiology and Nuclear Medicine, University Medical Center Mannheim, Heidelberg University, Mannheim, Germany.

Received: 5 October 2012 Accepted: 26 October 2012

Published: 16 November 2012

\section{References}

1. Bertuccio P, Chatenoud L, Levi F, Praud D, Ferlay J, Negri E, Malvezzi M, La Vecchia C: Recent patterns in gastric cancer: a global overview. Int J Cancer 2009, 125:666-673.

2. Siegel R, Ward E, Brawley O, Jemal A: Cancer statistics, 2011: the impact of eliminating socioeconomic and racial disparities on premature cancer deaths. CA Cancer J Clin 2011, 61:212-236.

3. Boyle P, Ferlay J: Cancer incidence and mortality in Europe, 2004. Ann Oncol 2005, 16:481-488.

4. Jemal A, Bray F, Center MM, Ferlay J, Ward E, Forman D: Global cancer statistics. CA Cancer J Clin 2011, 61:69-90.

5. Botterweck AA, Schouten $L$, Volovics A, Dorant E, van Den Brandt PA: Trends in incidence of adenocarcinoma of the oesophagus and gastric cardia in ten European countries. Int J Epidemiol 2000, 29:645-654.

6. Powell J, McConkey CC: The rising trend in oesophageal adenocarcinoma and gastric cardia. Eur J Cancer Prev 1992, 1:265-269.

7. Blot WJ, Devesa SS, Kneller RW, Fraumeni JF Jr: Rising incidence of adenocarcinoma of the esophagus and gastric cardia. JAMA 1991, 265:1287-1289.

8. Okabayashi T, Gotoda T, Kondo H, Inui T, Ono H, Saito D, Yoshida S, Sasako M, Shimoda T: Early carcinoma of the gastric cardia in Japan: is it different from that in the West? Cancer 2000, 89:2555-2559.

9. Chung JW, Lee GH, Choi KS, Kim DH, Jung KW, Song HJ, Choi KD, Jung HY, $\mathrm{Kim} \mathrm{JH}$, Yook JH, et al: Unchanging trend of esophagogastric junction adenocarcinoma in Korea: experience at a single institution based on Siewert's classification. Diseases of the esophagus: official journal of the International Society for Diseases of the Esophagus / ISDE 2009, 22:676-681.

10. Lagergren J, Bergstrom R, Nyren O: Association between body mass and adenocarcinoma of the esophagus and gastric cardia. Ann Intern Med 1999, 130:883-890.

11. Inoue M, Tajima K, Hirose K, Kuroishi T, Gao CM, Kitoh T: Life-style and subsite of gastric cancer-joint effect of smoking and drinking habits. Int J Cancer 1994, 56:494-499.

12. Stein $H J$, Feith M, Siewert JR: Cancer of the esophagogastric junction. Surg Oncol 2000, 9:35-41.

13. Siewert JR, Holscher AH, Becker K, Gossner W: [Cardia cancer: attempt at a therapeutically relevant classification]. Der Chirurg; Zeitschrift fur alle Gebiete der operativen Medizen 1987, 58:25-32.
14. Wijnhoven BP, Siersema PD, Hop WC, van Dekken H, Tilanus HW: Adenocarcinomas of the distal oesophagus and gastric cardia are one clinical entity. Rotterdam Oesophageal Tumour Study Group. Br J Surg 1999, 86:529-535.

15. Kodera $Y$, Yamamura $Y$, Shimizu Y, Torii A, Hirai T, Yasui K, Morimoto T, Kato $\mathrm{T}$ : Adenocarcinoma of the gastroesophageal junction in Japan: relevance of Siewert's classification applied to 177 cases resected at a single institution. J Am Coll Surg 1999, 189:594-601.

16. Suh YS, Han DS, Kong SH, Lee HJ, Kim YT, Kim WH, Lee KU, Yang HK: Should adenocarcinoma of the esophagogastric junction be classified as esophageal cancer? A comparative analysis according to the seventh AJCC TNM classification. Ann Surg 2012, 255:908-915.

17. Rice TW, Blackstone EH, Rusch W: 7th edition of the AJCC Cancer Staging Manual: esophagus and esophagogastric junction. Ann Surg Oncol 2010, 17:1721-1724

18. Edge SB (Ed): AJCC cancer staging manual. 7 editionth edition. New York, NY [u.a.]: Springer; 2010.

19. Hartgrink HH, van de Velde CJ, Putter H, Bonenkamp JJ, Klein Kranenbarg E, Songun I, Welvaart K, van Krieken JH, Meijer S, Plukker JT, et al: Extended lymph node dissection for gastric cancer: who may benefit? Final results of the randomized Dutch gastric cancer group trial. J Clin Oncol 2004, 22:2069-2077.

20. Songun I, Putter H, Kranenbarg EM, Sasako M, van de Velde CJ: Surgical treatment of gastric cancer: 15-year follow-up results of the randomised nationwide Dutch D1D2 trial. Lancet Oncol 2010, 11:439-449.

21. Cuschieri A, Weeden S, Fielding J, Bancewicz J, Craven J, Joypaul V, Sydes M, Fayers $\mathrm{P}$ : Patient survival after D1 and D2 resections for gastric cancer: long-term results of the MRC randomized surgical trial. Surgical Co-operative Group. Br J Cancer 1999, 79:1522-1530.

22. Degiuli M, Sasako M, Ponti A: Morbidity and mortality in the Italian Gastric Cancer Study Group randomized clinical trial of D1 versus D2 resection for gastric cancer. Br J Surg 2010, 97:643-649.

23. Tamura S, Takeno A, Miki H: Lymph node dissection in curative gastrectomy for advanced gastric cancer. Int J Surg Oncol 2011, 2011:748745.

24. Van Cutsem E, Van de Velde C, Roth A, Lordick F, Kohne CH, Cascinu S, Aapro $M$ : Expert opinion on management of gastric and gastro-oesophageal junction adenocarcinoma on behalf of the European Organisation for Research and Treatment of Cancer (EORTC)-gastrointestinal cancer group. Eur J Cancer 2008, 44:182-194.

25. Mariette C, Piessen G: Oesophageal cancer: how radical should surgery be? Eur J Surg Oncol 2012, 38:210-213.

26. D'Angelica M, Gonen M, Brennan MF, Turnbull AD, Bains M, Karpeh MS: Patterns of initial recurrence in completely resected gastric adenocarcinoma. Ann Surg 2004, 240:808-816.

27. Macdonald JS, Smalley SR, Benedetti J, Hundahl SA, Estes NC, Stemmermann GN, Haller DG, Ajani JA, Gunderson LL, Jessup JM, Martenson JA: Chemoradiotherapy after surgery compared with surgery alone for adenocarcinoma of the stomach or gastroesophageal junction. N Engl J Med 2001, 345:725-730.

28. Kim S, Lim DH, Lee J, Kang WK, MacDonald JS, Park CH, Park SH, Lee SH, Kim K, Park JO, et al: An observational study suggesting clinical benefit for adjuvant postoperative chemoradiation in a population of over 500 cases after gastric resection with D2 nodal dissection for adenocarcinoma of the stomach. Int J Radiat Oncol Biol Phys 2005, 63:1279-1285

29. Smalley SR, Benedetti JK, Haller DG, Hundahl SA, Estes NC, Ajani JA, Gunderson LL, Goldman B, Martenson JA, Jessup JM, et al: Updated Analysis of SWOG-Directed Intergroup Study 0116: A Phase III Trial of Adjuvant Radiochemotherapy Versus Observation After Curative Gastric Cancer Resection. J Clin Oncol 2012, 30:2327-2333.

30. Brooks GA, Enzinger PC, Fuchs CS: Adjuvant therapy for gastric cancer: revisiting the past to clarify the future. J Clin Oncol 2012, 30:2297-2299.

31. Bajetta E, Buzzoni R, Mariani L, Beretta E, Bozzetti F, Bordogna G, Aitini E, Fava S, Schieppati G, Pinotti G, et al: Adjuvant chemotherapy in gastric cancer: 5 -year results of a randomised study by the Italian Trials in Medical Oncology (ITMO) Group. Ann Oncol 2002, 13:299-307.

32. Bouche $O$, Ychou M, Burtin P, Bedenne L, Ducreux M, Lebreton G, Baulieux J, Nordlinger B, Martin C, Seitz JF, et al: Adjuvant chemotherapy with 5fluorouracil and cisplatin compared with surgery alone for gastric cancer: 7year results of the FFCD randomized phase III trial (8801). Ann Oncol 2005, 16:1488-1497. 
33. Nitti D, Wils J, Dos Santos JG, Fountzilas G, Conte PF, Sava C, Tres A, Coombes RC, Crivellari D, Marchet A, et al: Randomized phase III trials of adjuvant FAMTX or FEMTX compared with surgery alone in resected gastric cancer. A combined analysis of the EORTC GI Group and the ICCG. Ann Oncol 2006, 17:262-269.

34. Cunningham D, Allum WH, Stenning SP, Thompson JN, Van de Velde CJ, Nicolson M, Scarffe JH, Lofts FJ, Falk SJ, Iveson TJ, et al: Perioperative chemotherapy versus surgery alone for resectable gastroesophageal cancer. N Engl J Med 2006, 355:11-20.

35. Bickenbach K, Strong VE: Comparisons of Gastric Cancer Treatments: East vs. West. Journal of gastric cancer 2012, 12:55-62.

36. D'Ugo D, Rausei S, Biondi A, Persiani R: Preoperative treatment and surgery in gastric cancer: friends or foes? Lancet Oncol 2009, 10:191-195.

37. Lordick F, Siewert JR: Perioperative chemotherapy vs. surgery alone in resectable gastroesophageal carcinomas. Results of the MAGIC study. Der Chirurg; Zeitschrift fur alle Gebiete der operativen Medizen 2006, 77:1166-1167.

38. Meyer HJ, Holscher AH, Lordick F, Messmann H, Monig S, Schumacher C, Stahl M, Wilke H, Mohler M: Current S3 guidelines on surgical treatment of gastric carcinoma. Der Chirurg; Zeitschrift fur alle Gebiete der operativen Medizen 2012, 83:31-37.

39. Mihaljevic AL, Friess $\mathrm{H}$, Schuhmacher C: Clinical trials in gastric cancer and the future. J Surg Oncol 2012, http://www.ncbi.nlm.nih.gov/pubmed/ 22514058

40. Dikken JL, van Sandick JW, Maurits Swellengrebel HA, Lind PA, Putter H, Jansen EP, Boot H, van Grieken NC, van de Velde CJ, Verheij M, Cats A: Neoadjuvant chemotherapy followed by surgery and chemotherapy or by surgery and chemoradiotherapy for patients with resectable gastric cancer (CRITICS). BMC Cancer 2011, 11:329.

41. Klautke G, Fietkau R: Significance of radiation therapy for adenocarcinomas of the esophagus, gastroesophageal junction and gastric cancer with special reference to the MAGIC trial. Strahlenther Onkol 2007, 183:163-169.

42. Sakuramoto S, Sasako M, Yamaguchi T, Kinoshita T, Fujii M, Nashimoto A, Furukawa H, Nakajima T, Ohashi Y, Imamura H, et al: Adjuvant chemotherapy for gastric cancer with $\mathrm{S}-1$, an oral fluoropyrimidine. $N$ Engl J Med 2007, 357:1810-1820.

43. Sasako M, Sakuramoto S, Katai H, Kinoshita T, Furukawa H, Yamaguchi T, Nashimoto A, Fujii M, Nakajima T, Ohashi Y: Five-year outcomes of a randomized phase III trial comparing adjuvant chemotherapy with S-1 versus surgery alone in stage II or III gastric cancer. J Clin Oncol 2011, 29:4387-4393.

44. Nakajima T, Kinoshita T, Nashimoto A, Sairenji M, Yamaguchi T, Sakamoto J, Fujiya T, Inada T, Sasako M, Ohashi Y: Randomized controlled trial of adjuvant uracil-tegafur versus surgery alone for serosa-negative, locally advanced gastric cancer. Br J Surg 2007, 94:1468-1476.

45. Bang YJ, Kim YW, Yang HK, Chung HC, Park YK, Lee KH, Lee KW, Kim YH, Noh SI, Cho JY, et al: Adjuvant capecitabine and oxaliplatin for gastric cancer after D2 gastrectomy (CLASSIC): a phase 3 open-label, randomised controlled trial. Lancet 2012, 379:315-321.

46. Ku GY, Ilson DH: Adjuvant therapy in esophagogastric adenocarcinoma: controversies and consensus, Gastrointestinal cancer research. GCR 2012, 5:85-92.

47. Mariette C, Piessen G, Triboulet JP: Therapeutic strategies in oesophageal carcinoma: role of surgery and other modalities. Lancet Oncol 2007, 8:545-553.

48. Ando N, lizuka T, Ide H, Ishida K, Shinoda M, Nishimaki T, Takiyama W, Watanabe $\mathrm{H}$, Isono $\mathrm{K}$, Aoyama $\mathrm{N}$, et al: Surgery plus chemotherapy compared with surgery alone for localized squamous cell carcinoma of the thoracic esophagus: a Japan Clinical Oncology Group StudyJCOG9204. J Clin Oncol 2003, 21:4592-4596.

49. Arnott SJ, Duncan W, Gignoux M, Hansen HS, Launois B, Nygaard K, Parma MK, Rousell A, Spilopoulos G, Stewart G, et al: Preoperative radiotherapy for esophageal carcinoma. Cochrane Database Syst Rev 2005, CD001799. http://www.ncbi.nlm.nih.gov/pubmed/16235286.

50. Zieren HU, Muller JM, Jacobi CA, Pichlmaier H, Muller RP, Staar S: Adjuvant postoperative radiation therapy after curative resection of squamous cell carcinoma of the thoracic esophagus: a prospective randomized study. World J Surg 1995, 19:444-449.

51. Sjoquist KM, Burmeister BH, Smithers BM, Zalcberg JR, Simes RJ, Barbour A, Gebski V: Survival after neoadjuvant chemotherapy or chemoradiotherapy for resectable oesophageal carcinoma: an updated meta-analysis. Lancet Oncol 2011, 12:681-692.

52. Allum WH, Stenning SP, Bancewicz J, Clark PI, Langley RE: Long-term results of a randomized trial of surgery with or without preoperative chemotherapy in esophageal cancer. J Clin Oncol 2009, 27:5062-5067.

53. Kelsen DP, Winter KA, Gunderson LL, Mortimer J, Estes NC, Haller DG, Ajani JA, Kocha W, Minsky BD, Roth JA, Willett CG: Long-term results of RTOG trial 8911 (USA Intergroup 113): a random assignment trial comparison of chemotherapy followed by surgery compared with surgery alone for esophageal cancer. J Clin Oncol 2007, 25:3719-3725.

54. Fiorica F, Di Bona D, Schepis F, Licata A, Shahied L, Venturi A, Falchi AM, Craxi A, Camma C: Preoperative chemoradiotherapy for oesophageal cancer: a systematic review and meta-analysis. Gut 2004, 53:925-930.

55. Urschel JD, Vasan H: A meta-analysis of randomized controlled trials that compared neoadjuvant chemoradiation and surgery to surgery alone for resectable esophageal cancer. Am J Surg 2003, 185:538-543.

56. Walsh TN, Noonan N, Hollywood D, Kelly A, Keeling N, Hennessy TP: A comparison of multimodal therapy and surgery for esophageal adenocarcinoma. N Engl J Med 1996, 335:462-467.

57. Stahl M, Walz MK, Stuschke M, Lehmann N, Meyer HJ, Riera-Knorrenschild J, Langer P, Engenhart-Cabillic R, Bitzer M, Konigsrainer A, et al: Phase III comparison of preoperative chemotherapy compared with chemoradiotherapy in patients with locally advanced adenocarcinoma of the esophagogastric junction. J Clin Oncol 2009, 27:851-856.

58. Ychou M, Boige V, Pignon JP, Conroy T, Bouche O, Lebreton G, Ducourtieux M, Bedenne L, Fabre JM, Saint-Aubert B, et al: Perioperative chemotherapy compared with surgery alone for resectable gastroesophageal adenocarcinoma: an FNCLCC and FFCD multicenter phase III trial. J Clin Oncol 2011, 29:1715-1721.

59. van Hagen P, Hulshof MC, van Lanschot JJ, Steyerberg EW, van Berge Henegouwen MI, Wijnhoven BP, Richel DJ, Nieuwenhuijzen GA, Hospers GA, Bonenkamp JJ, et al: Preoperative chemoradiotherapy for esophageal or junctional cancer. N Engl J Med 2012, 366:2074-2084

60. Lee J, Lim Do H, et al: Phase III trial comparing capecitabine plus cisplatin versus capecitabine plus cisplatin with concurrent capecitabine radiotherapy in completely resected gastric cancer with D2 lymph node dissection: the ARTIST trial. J Clin Oncol 2012, 30:268-273.

61. Zhu WG, Xua DF, Pu J, Zong CD, Li T, Tao GZ, Ji FZ, Zhou XL, Han JH, Wang $\mathrm{CS}$, et al: A randomized, controlled, multicenter study comparing intensity-modulated radiotherapy plus concurrent chemotherapy with chemotherapy alone in gastric cancer patients with D2 resection. Radiother Oncol 2012, http://www.ncbi.nlm.nih.gov/pubmed?term=zhu\% 20xua\%20a\%20randomized\%2C\%20controlled\%2C.

62. Yu C, Yu R, Zhu W, Song Y, Li T: Intensity-modulated radiotherapy combined with chemotherapy for the treatment of gastric cancer patients after standard D1/D2 surgery. J Cancer Res Clin Oncol 2012, 138:255-259.

63. Dikken JL, Jansen EP, Cats A, Bakker B, Hartgrink HH, Kranenbarg EM, Boot $\mathrm{H}$, Putter H, Peeters KC, van de Velde CJ, Verheij M: Impact of the extent of surgery and postoperative chemoradiotherapy on recurrence patterns in gastric cancer. J Clin Oncol 2010, 28:2430-2436.

64. Smalley SR, Gunderson L, Tepper J, Martenson JA Jr, Minsky B, Willett C, Rich T: Gastric surgical adjuvant radiotherapy consensus report: rationale and treatment implementation. Int J Radiat Oncol Biol Phys 2002, 52:283-293.

65. Gunderson LL, Sosin H: Adenocarcinoma of the stomach: areas of failure in a re-operation series (second or symptomatic look) clinicopathologic correlation and implications for adjuvant therapy. Int J Radiat Oncol Biol Phys 1982, 8:1-11.

66. Caudry M, Ratoanina JL, Escarmant P, Maire JP: [Target volume in radiotherapy of gastric adenocarcinoma]. Cancer Radiother 2001, 5:523-533.

67. Saikawa Y, Kubota T, Kumagai K, Nakamura R, Kumai K, Shigematsu N, Kubo A, Kitajima M, Kitagawa Y: Phase II study of chemoradiotherapy with S-1 and low-dose cisplatin for inoperable advanced gastric cancer. Int $J$ Radiat Oncol Biol Phys 2008, 71:173-179.

68. Jansen EP, Saunders MP, Boot H, Oppedijk V, Dubbelman R, Porritt B, Cats A, Stroom J, Valdes Olmos R, Bartelink H, Verheij M: Prospective study on late renal toxicity following postoperative chemoradiotherapy in gastric cancer. Int $\rfloor$ Radiat Oncol Biol Phys 2007, 67:781-785.

69. Welz S, Hehr T, Kollmannsberger C, Bokemeyer C, Belka C, Budach W: Renal toxicity of adjuvant chemoradiotherapy with cisplatin in gastric cancer. Int J Radiat Oncol Biol Phys 2007, 69:1429-1435.

70. Oblak I, Velenik V, Anderluh F, Strojan P: Results of adjuvant radiochemotherapy for gastric adenocarcinoma in Slovenia. Eur I Surg Oncol 2007, 33:982-987. 
71. Bese NS, Buyukunal E, Ozguroglu M, Demir G, Yildirim A, Mandel NM, Demirelli F, Serdengecti S, Ober A: Toxicity and survival results of a phase II study investigating the role of postoperative chemoradioimmunotherapy for gastric adenocarcinoma. Strahlenther Onkol 2005, 181:652-659.

72. Corletto D, lori M, Paiusco M, Brait L, Broggi S, Ceresoli G, lotti C, Calandrino $\mathrm{R}$, Fiorino $\mathrm{C}$ : Inverse and forward optimization of one- and twodimensional intensity-modulated radiation therapy-based treatment of concave-shaped planning target volumes: the case of prostate cancer. Radiother Oncol 2003, 66:185-195.

73. Wieland P, Dobler B, Mai S, Hermann B, Tiefenbacher U, Steil V, Wenz F, Lohr F: IMRT for postoperative treatment of gastric cancer: covering large target volumes in the upper abdomen: a comparison of a stepand-shoot and an arc therapy approach. Int J Radiat Oncol Biol Phys 2004, 59:1236-1244.

74. Lohr F, Dobler B, Mai S, Hermann B, Tiefenbacher U, Wieland P, Steil V, Wenz F: Optimization of dose distributions for adjuvant locoregional radiotherapy of gastric cancer by IMRT. Strahlenther Onkol 2003, 179:557-563.

75. Dahele M, Skinner M, Schultz B, Cardoso M, Bell C, Ung YC: Adjuvant radiotherapy for gastric cancer: A dosimetric comparison of 3-dimensional conformal radiotherapy, tomotherapy and conventional intensity modulated radiotherapy treatment plans. Medical dosimetry: official journal of the American Association of Medical Dosimetrists 2010, 35:115-121.

76. Boda-Heggemann J, Haneder S, Konstandin S, Schad L, Wenz F, Michaely H, Lohr F: Assessment of 3D-conformal Radiotherapy (3DCRT) and Imageguided Intensity Modulated Radiotherapy (IG-IMRT) Induced Renal Damage by Means of Functional MR-imaging and 23Na-MR-imaging. Int J Radiat Oncol Biol Phys 2011, 81:S326-S327.

77. Haneder S, Michaely HJ, Schoenberg SO, Konstandin S, Schad LR, Siebenlist K, Wertz H, Wenz F, Lohr F, Boda-Heggemann J: Assessment of renal function after conformal radiotherapy and intensity modulated radiotherapy by functional ${ }^{1} \mathrm{H}-\mathrm{MR}$-imaging and ${ }^{23} \mathrm{Na}-\mathrm{MR}$-imaging. Strahlenther Onkol, in press.

78. Kole TP, Aghayere O, Kwah J, Yorke ED, Goodman KA: Comparison of heart and coronary artery doses associated with intensity-modulated radiotherapy versus three-dimensional conformal radiotherapy for distal esophageal cancer. Int J Radiat Oncol Biol Phys 2012, 83:1580-1586.

79. Chakravarty T, Crane CH, Ajani JA, Mansfield PF, Briere TM, Beddar AS, Mok $H$, Reed VK, Krishnan S, Delclos ME, Das P: Intensity-modulated radiation therapy with concurrent chemotherapy as preoperative treatment for localized gastric adenocarcinoma. Int J Radiat Oncol Biol Phys 2012, 83:581-586.

80. Wolff D, Stieler F, Hermann B, Heim K, Clausen S, Fleckenstein J, Polednik M, Stei $\checkmark$, Wenz F, Lohr F: Clinical implementation of volumetric intensity-modulated arc therapy (VMAT) with ERGO++. Strahlenther Onkol 2010, 186:280-288.

81. Rochet N, Sterzing F, Jensen A, Dinkel J, Herfarth K, Schubert K, Eichbaum M, Schneeweiss A, Sohn C, Debus J, Harms W: Helical tomotherapy as a new treatment technique for whole abdominal irradiation. Strahlenther Onkol 2008, 184:145-149.

82. Martin S, Chen JZ, Rashid Dar A, Yartsev S: Dosimetric comparison of helical tomotherapy, RapidArc, and a novel IMRT \& Arc technique for esophageal carcinoma. Radiother Oncol 2011, 101:431-437.

83. Fan T, Jiang G, Suo Z, Liu H, Xu P, Ji Z, Zhang L, Yang G: Down-regulation of the apoptosis-inducing factor or Bcl-2 inhibitor of transcription by RNA interference can alleviate TAp63gamma-induced apoptosis in esophageal squamous carcinoma EC9706 cells. Int J Oncol 2009, 35:359-367.

84. Nicolini G, Ghosh-Laskar S, Shrivastava SK, Banerjee S, Chaudhary S, Agarwal JP, Munshi A, Clivio A, Fogliata A, Mancosu P, et al: Volumetric Modulation Arc Radiotherapy With Flattening Filter-Free Beams Compared With Static Gantry IMRT and 3D Conformal Radiotherapy for Advanced Esophageal Cancer: A Feasibility Study. Int J Radiat Oncol Biol Phys 2012, 84:553-560.

85. Vivekanandan N, Sriram P, Kumar SA, Bhuvaneswari N, Saranya K: Volumetric modulated arc radiotherapy for esophageal cancer. Medical dosimetry: official journal of the American Association of Medical Dosimetrists 2012, 37:108-113.

86. Van Benthuysen L, Hales L, Podgorsak MB: Volumetric modulated arc therapy vs. IMRT for the treatment of distal esophageal cancer. Medical dosimetry: official journal of the American Association of Medical Dosimetrists 2011, 36:404-409.
87. Hu W, Ye J, Wang J, Xu Q, Zhang Z: Incorporating breath holding and image guidance in the adjuvant gastric cancer radiotherapy: a dosimetric study. Radiat Oncol 2012, 7:98.

88. Li W, Moseley DJ, Bissonnette JP, Purdie TG, Bezjak A, Jaffray DA: Setup reproducibility for thoracic and upper gastrointestinal radiation therapy: Influence of immobilization method and on-line cone-beam CT guidance. Medical dosimetry: official journal of the American Association of Medical Dosimetrists 2010, 35:287-296.

89. Dawson LA, Jaffray DA: Advances in image-guided radiation therapy. J Clin Oncol 2007, 25:938-946.

90. Fuss M, Salter BJ, Cavanaugh SX, Fuss C, Sadeghi A, Fuller CD, Ameduri A, Hevezi JM, Herman TS, Thomas CR Jr: Daily ultrasound-based imageguided targeting for radiotherapy of upper abdominal malignancies. Int J Radiat Oncol Biol Phys 2004, 59:1245-1256.

91. Boda-Heggemann J, Guckenberger M, Ganswindt U, Belka C, Wertz H, Blessing M, Wenz F, Fuss M, Lohr F: [Image-guided radiation therapy]. Radiologe 2012, 52:213-221.

92. Boda-Heggemann J, Lohr F, Wenz F, Flentje M, Guckenberger M: kV cone-beam CT-based IGRT: a clinical review. Strahlenther Onkol 2011, 187:284-291.

93. Boda-Heggemann J, Mennemeyer P, Wertz H, Riesenacker N, Kupper B, Lohr $F$, Wenz F: Accuracy of ultrasound-based image guidance for daily positioning of the upper abdomen: an online comparison with cone beam CT. Int J Radiat Oncol Biol Phys 2009, 74:892-897.

94. Welsh J, Gomez D, Palmer MB, Riley BA, Mayankkumar AV, Komaki R, Dong L, Zhu XR, Likhacheva A, Liao Z, et al: Intensity-modulated proton therapy further reduces normal tissue exposure during definitive therapy for locally advanced distal esophageal tumors: a dosimetric study. Int J Radiat Oncol Biol Phys 2011, 81:1336-1342.

95. Boda-Heggemann J, Hofheinz RD, Weiss C, Mennemeyer P, Mai SK, Hermes $P$, Wertz H, Post S, Massner B, Hieber U, et al: Combined adjuvant radiochemotherapy with IMRT/XELOX improves outcome with low renal toxicity in gastric cancer. Int J Radiat Oncol Biol Phys 2009, 75:1187-1195.

96. Minn AY, Hsu A, La T, Kunz P, Fisher GA, Ford JM, Norton JA, Visser B, Goodman KA, Koong AC, Chang DT: Comparison of intensity-modulated radiotherapy and 3-dimensional conformal radiotherapy as adjuvant therapy for gastric cancer. Cancer 2010, 116:3943-3952.

97. Hofheinz RD, Wenz F, Lukan N, Mai S, Kripp M, Staiger W, Schwarzbach M, Willeke F, Mohler M, Post S, Hochhaus A: Oxaliplatin and capecitabinebased chemoradiotherapy for gastric cancer-an extended phase I MARGIT and AIO trial. Int J Radiat Oncol Biol Phys 2009, 73:142-147.

98. Boda-Heggemann J, Weiss C, Schneider V, Hofheinz R, Haneder S, Michaely HJ, Wertz H, Post S, Hochhaus A, Wenz F, Lohr F: Adjuvante Radiochemotherapie mit IMRT/XELOX verbessert das Gesamt- und krankheitsfreie Überleben des fortgeschrittenen Magenkarzinoms gegenüber 3DCRT/5FU-FA auch im Langzeit-Follow-up. Strahlenther Onkol 2012, 188(Sondernr. 1):V02-05.

99. Lin SH, Wang L, Myles B, Thall PF, Hofstetter WL, Swisher SG, Ajani JA, Cox JD, Komaki R, Liao Z: Propensity Score-based Comparison of Long-term Outcomes With 3-Dimensional Conformal Radiotherapy vs IntensityModulated Radiotherapy for Esophageal Cancer. Int J Radiat Oncol Biol Phys 2012, http://www.ncbi.nlm.nih.gov/pubmed?term=lin\%20wang\% 20propensity\%20score-based.

doi:10.1186/1748-717X-7-192

Cite this article as: Buergy et al:: Radiotherapy for tumors of the stomach and gastroesophageal junction - a review of its role in multimodal therapy. Radiation Oncology 2012 7:192. 